\title{
A POSSE NO CÓDIGO CIVIL BRASILEIRO
}

\author{
EUCLIDES DE MESQUITA \\ Livre Docente de Direito Civil
}

Em verdade, não se deveria trasladar para um código moderno a noção de posse do direito justinianeu, extraída dos jurisconsultos que forneceram aos compiladores bizantinos o texto do Digesto.

A verdadeira noção de posse deveria ser, no direito atual, no sentido comum de ocupação, de qualquer poder de fato exercido sôbre alguma coisa, dispensando-se a preocupação de lhe dar função técnica, a exemplo dos fragmentos do Digesto, para significar a posse jurídica nos dois aspectos: modo aquisitivo - possessio ad usu capionem e defesa contra os atos de força - possessio ad interdicta.

No Dig. Lib. XLI, Tit. II, I, Paulus define: "Possessio" "appellata est (ut et Labeo ait) a sedibus" "quasi positio, quia naturaliter tenetur ab eo," "qui ei insistit".

A posse é, de certo, um estado ou uma posição de fato, em que se encontra o homem, em referência a uma coisa, e que lhe permite realizar a utilização econômica dessa coisa, auferindo direta ou indiretamente, e por qualquer forma, para a satisfação de suas necessidades biológicas e sociais, as vantagens e as utilidades a que a coisa se presta.

Representa, sem dúvida, no mundo atual, a função de possibilitar, independente do domínio, o usơ e gôzo dos bens.

Assiste razão a Salleiles (La possession des meubles) ao dizer que a posse é um poder de fato independente sôbre as coișas.

À ciência romana deve-se, certamente, atribuir a êsse poder o sentido de posse jurídica, nos dois aspectos acima enumerados: modo aquisitivo (possessio ad usu capionem) a defesa contra os atos de fôrça (possessio ad interdicta).

Savigny revela (Traité de la Possession), que êsses dois efeitos caracterizam no direito romano a posse jurídica, em oposição à me- 
ra detenção, desprovida, contra a violência, de qualquer ação possessória.

À noção de posse dedica extensa dissertação sôbre a posse em direito romano, com inúmeras notas e adições, aceitando algumas críticas e repelindo outras, na maior parte feitas ao seu estudo, durante os 33 anos entre a primeira edição e a sexta.

Insiste, todavia, e cada vez com maior ênfase, na noção de posse jurídica no direito romano pelos dois efeitos eventuais, uso capião e interdito, com uma penetrante análise do que se contém nas Pandectas.

De igual maneira, o Código Civil brasileiro, como o Corpus Juris Civilis (D. L. XLI, T. II, § I, Paulus - Quod autem diximus, et corpore, et animo adquirere nos debere possessionem...) considera a posse, cuja noção e classificação se encontram nos Capítulos (capítulos III e V, Livro II) pela importância jurídica dos dois efeitos possíveis: um defensivo e outro aquisitivo.

Do defensivo, tratado nos arts. 499 a 509 e o 523 do Código; do aquisitivo, nos arts. 550 a 553, Livro II, Tit. II, Seção IV), 618 (Livro II, Cap. III, Seção IV).

De consequência, o Código só concede a proteção possessória ao possuidor jurídico de que trata nos arts. 485, 486 e 487.

Mais acertado seria proteger contra a violência o detentor da coisa, o possuidor em geral, não só o jurídico.

Nosso Código não definiu a posse, mas do seu conceito sôbre o possuidor pode-se deduzir uma definição e dizer: posse é, de fato, o exercício, pleno ou não, de algum dos poderes inerentes ao domínio ou propriedade.

Diz-se - de fato - o exercício, porque se pretende que ela é o exercício do domínio ou propriedade, segundo o "conceito de Ihering, ao qual acrescenta Clóvis, em seu Código Civil, vol. 3. "que nossa lei foi a primeira "a consagrar inteira e francamente a doutrina sôbre a posse". Há quem conteste isto; mas não vale a pena insistir no assunto.

Diz-se pleno ou não, porque o exercício pode abranger todos os poderes sôbre a coisa ou apenas alguns, como acontece na enfiteuse, no usofruto etc.

Diz-se algum dos poderes inerentes ao domínio ou propriedade, - porque pode até restringir-se a um só daqueles poderes, como acontece na habitação.

Nosso código se destacou, assim, não só da definição de posse da teoria tradicional, mesmo modificada e alargada, pois que não mais falou do corpo e do animo; como também se destacou das defi. 
nições dos códigos, desde o Code Napoleón e dos que a êste tomaram por modêlo, até os da Alemanha e da Suiça, uma vez que não mais falou da detenção de uma coisa ou gôzo de um direito, nem disse ser a posse o poder de fato sôbre as coisas, ou o senhorio efetivo das coisas.

Preferiu aquela fórmula: exercício do domínio ou propriedade. Todavia, com isso o código não nos leva a uma noção mais perfeita da posse. Ao contrário disso, induziu-nos, pelas suas expressões, à fórmula confusa de Ihering, que o tornou também contraditória e incompleta.

Em realidade, é confusa porque o exercício do dominio ou propriedade, tanto compreende a posse como a detenção, visto que ambas são manifeståções de nossa vontade sôbre as coisas, são aparências ou exterioridades de nossas relações com elas, e, entretanto, no ensino do próprio lhering, a detenção e a posse são fatos distintos, tendo a primeira, como êle mesmo o declara, efeitos menores do que a segundo; sendo aquela um simples fato, e esta, direito.

Depois, é contraditória porque, definindo possuidor aquêle que tem de fato o exercício, pleno ou não, de algum dos poderes do domínio ou propriedade, não podia lògicamente, declarar possuidor o credor pignoratício, o usufrutuário e o locatário que exercem temporàriamente o poder sôbre as coisas (possuidores diretos) e, ao mesmo tempo, também possuidores aqueles de quem êstes houveram as coisas e que, portanto, não exercem poder nenhum porque os transferiram aos primeiros (possuidores indiretos).

Finalmente, é incompleta porque, como observam Clóvis, Tito Fulgêncio e Azevedo Marques, o código não nos dá, em seu art. 485, o conceito integral da posse, obrigando-nos a ir procurar o complemento da noção da coisa em nome de outrem e em cumprimento às ordens dêle, como o operário e o empregado, na conformidade do art. 487; e que êle exclui os que têm a coisa em seu poder por atos de mera permisıão ou tolerância de seus danos, como acontece nos casos de passagem por terreno alheio ou em empréstimo de qualquer coisa, enquanto o proprietário consente, na conformidade do art. 497.

Foi mister que êsses dois artigos nos informassem quem não é possuidor para podermos ter uma noção mais precisa de quem é possuidor.

Adverte Azevedo Marques que, igualmente, não disse tão pouco o código que o exercício do possuidor sôbre a coisa deverá ser feito em nome próprio e não em nome alheio.

Assim, o código não nos deu uma boa definição de posse, quando, entretanto, a posse não passa de poder sôbre as coisas, seja de fato ou de direito, seja um poder atual ou virtual, seja de coi- 
sas que estão ao alcance de nossa vista ou que estão apenas ao alcance de nossa vontade, até onde seja possível levar a ação desta, porque - o exercício p'eno ou não do domínio ou propriedade pressupõe, inevitàvelmente êsse poder, ou não existe.

Não vejo, pois, razão para se negar a proteção possessória a que, nos têrmos do art. 487 "achando-se em relação de dependência para" "com terceiros, conserva a posse em nome dêste", quando terceiro o perturbe nela ou o esbulhe.

Acionando, o perturbador ou esbulhador, em seu próprio nome, não impediria a ação do preponente', como "res inter alios". Porque tolher ao preposto essa gestão de negócios? Como poderia ser útil quando não fôsse encontrado o preponente? Pelo direito romano, na ausência de preponente competia ao preposto a ação possessória (Cód. VIII, 5 - Si per vim vel alio modo absentis perturbata sit possessio).

Desatendendo o sábio conselho de lavolenus (D. Liv. L. Tit. XVII, 202 - Omnis definitio in iure civili periculosa est), o código, em seu artigo 485, considera "possuidor todo aquêle que tem da fato o exercício pleno ou não, de alguns dos poderes inerentes ao domínio, ou propriedade".

Os artigos seguintes, 486 e 487, desfazem a definição ínsita no art. 485 que -se apresenta inexata.

$E^{\prime}$ certo que é direito inerente ao domínio utilizar da coisa e gozar de seus frutos, é pode-se afirmar que, no exercício dêsse usufruto, dito causal, está o cerne da propriedade. Mas, não se pode considerar possuidor o indivíduo que, sem permissão e conhecimento do proprietário, costuma dormir sôbre o telheiro existente no terreno de outrem e colher as frutas de um pomar contíguo.

Isto no caso de não haver licença, porque, em havendo a permissão ou tolerância, excluida estaria a posse pẹlo art. 497.

Nascido do devaneio doutrinário de lhering, repleto de heresias em matéria de posse no direito romano, o art. 486 atribui ao locatário a posse direta sôbre a coisa alugada. Para que? Para conferirThe o direito de recorrer às ações possessórias, quando perturbado? Não seria necessário. Bastaria declarar que as ações possessórias competeriam a quantos fôssem perturbados ou espoliados no seu poder sôbre alguma coisa.

$E^{\prime}$ de acrescentar ainda que, sem qualquer necessidade, o artigo modifica o sentido usual da palavra, para criar uma significação técnica. Se o locatário de uma casa no Bacachery, referindo-se a ela, dizer: "Possuo uma casa no Bacachery" faltará a verdade, porque não tem a propriedade daquele imóvel. O dono é outro.

Ressalta ainda, de maneira mais chocante, o art. 505 inserto 
no Capítulo da posse. Divide-se o artigo em dois períodos contraditórios, no segundo dos quais o legislador não parece lembrar-se da técnica adotada no art. 485, afirmando que "não se deve, entretanto, julgar a posse em favor daquele a quem evidentemente não pertence o domínio". E o domínio, evidentemente, não pertence ao locatário, nem às outras pessoas de que trata o art. 486.

Pela redação do art. 505, segunda parte, se o réu provar que a coisa disputada na ação possessória não pertence ao autor, mas a terceiro, a posse não será julgada em favor do autor perturbado ou espoliado. Julgada a improcedência da ação, caberia a vitória, contra o possuinte, ao violador da posse.

De certo, outra é o pensamento e outra a intenção do artigo, se verificarmos a história da instituição em nosso direito. A redação exata deveria ser esta: "Não se deve, entretanto, julgar a posse contra aquêle a quem evidentemente não pertence o domínio".

Em verdade, o caso é de "exceptio dominii" que os jurisconsultos reinois, como Mello Freire, in Instituciones Juris Civilis Lusitani, IV, 6. $.^{\circ}, 30$ - De interdicto retinendae - Interdicto retinendae, seu uti possidetis, agir actor, ut defendatur in sua possessione... ou Correia Téles - in Doutrina das Ações, § 191 -: "O réo, além "das excepções dos $\S \S 187$ e seguintes, póde oppôr: 1. ", "que a posse do autor é viciosa a respeito delle réo; $2^{\circ}$, ," que o autor se deu por esbulhado; $3 .^{\circ}$, excepção de domi-" "nio provado in continenti; $4 .^{\circ}$, prescripção". - admitiam na ação de manutenção de posse (uti possidetis), nunca na de esbulho.

O art. 505 procede de dois artigos da Consolidação das Leis Civis de Teixeira de Freitas: o 817 que não admite a defesa fundada em domínio sôbre a coisa esbulhada in verbis: "Não se admite "nas ações de fôrça a defesa fundada em domínio, ou em" "outro qualquer direito, que se alegue ter sôbre a cousa" esbulhada", e o 818, que a admite para se não julgar a posse em favor daquele a quem evidentemente não pertencer o domínio - inverbis: "Todavia, não se deve julgar a posse em favor" "daquele, a quem se mostra evidentemente não pertencer". "a propriedade".

Teixeira de Freitas funda o seu art. 808 no assento de 16 de fevereiro "Assento sôbre o 2..$^{\circ}$ quesito", e em Nota ao referido artigo 808 de sua Consolidação, exclama: "Eis uma interpretação lu"minosa, para não seguir-se (como diz o Ass.) um absurdo" "visível".

Lamentável engano do grande civilista: o assento de 16 de fevereiro de 1786 não interpretou legislação concernente à defesa 
nas ações possessórias. $\bigcirc$ "assento sôbre o segundo quesito" (1) destinava-se a resolver se a referência ao filho, ao neto, ao irmão, ao sobrinho, na lei de 9 de novembro de 1854, na sucessão de bens vinculados, era taxativa ou exemplificativa.

Decidiu-se, pelo Assento, que a referência era exemplificativa, operando-se a transmissão dos bens vinculados, na falta das pessoas indicadas na lei, mesmo ao parente colateral mais próximo, "em "que se verifique, sem dependência de maior discussão, a" "certeza e preferência indubitável dêste direito se deve jul-" "gar transmissível a posse, até para se não seguir o visível" "absurdo de se julgar nos interdictos restituitórios, e nos" "outros casos ocorrentes no Foro, a referida posse àquelle" "mesmo a que pelo processo e evidencia notória dos Autos "se deprehende não lhe dever ser julgada a propriedade".

E tanto maior é essa a verdadeira interpretação do Assento que, na justificação do assentado se observa, como num parêntese final, "até para se não seguir o visível absurdo de julgar nos in-" "terdictos restituitórios e nos outros casos ocorrentes no" "Foro, a referida posse àquelle mesmo a que pelo processo" "e evidência notória dos Autos, se deprehende não se lhe" "dever julgada a propriedade".

De fato, para comprovar que nenhuma dúvida havia quanto à inteligência da lei, vê-se no art. 915 da mesma Consolidação: "Se o "esbulhador tiver algum direito sôbre a cousa, perdel-o-ha" "em proveito do esbulhado". (Ord. IV, 56 pr. (2)

\footnotetext{
1 - Assento sôbre o segundo Quesito.

Quanto ao segundo, se assentou por uma muito ampla pluraliddae de votos, que as pessoas, de que falla a Lei para a mesma transmissão da posse nos bens de Morgado, desig. não gráos, exemplificativos e não taxativos ou restrictivos; porque na Linha Direta Descendente não póde deixar de se comprehender o Bisneto, terceiro Neto, e os mais seguintes, os quaes são indubitàvelmente chamados pelas Leis do Reino para successão dos Morgados. E na Linha Collateral, além do Irmão e Sobrinho, por identidade ude razão e força de comprehensão, se deve extender a disposição da Lé จo parente notoriamente mais próximo do último Administrador, sendo do sangue do Instituidor, ou o que tiver um parentesco próximo e indubitável com hum dos dous, vindo odos pela mesma linha, por onde vem o Morgado, por se mostrarem igualmente chamados pela Ordenação do Liv. 4. Tit. 100. § 2 . e fin. para a secessão dos bens vinculados; porque esta foi a intenção do Legislador em designar as referidas pessoas de Irmão e Sobrinho deduzida do espírito e mente da Lei, que quer, que a posse passe para aquelle, que tiver um verosimil e mais provável direito à propriedade. Nem o Principe se fôsse interrogado, no caso de haver parente próximo com as referidas circumstâncias, disporia de outra sorte; nem se deve entender, que elle quizesse graduar para a transmissão da posse da Linha Collateral os mesmos parentes, que graduou para o direito da Representação, não só porque isto impliç, attento o rigor dos têrmos da Linha Descendente em que a representação tem lugar em tôdos os gráos in infinitum; mas também porque o direito da transmissão da posse se regula por muitos diferentes princípios, os quais se dirigem a impedir o enorme abuso, que se fazia, de se apossarem pessoas estranhas dos bens vinculados, e ainda aqueles em gráo remoto e incerto, a quem verdadeiramente não pertencia o direito da sucessão, nem o domínio dos bens, e nesta precisa e justa consideração, havendo um parentesco próximo, em que se verifique, sem dependência de maior discussão, a certeza e preferência indubitável deste direito se deve julgar transmissível a posse, até para se não seguir o visivel absurdo de se julgar nos interdictos restifuitórios, e nos outros casos ocorrentes no Foro, a referida posse àquelle mesmo a que pelo procesos e evidencia notória dos Autos, se deprehende não lhe dever ser julgada a propriedade. "Colleç̧ão da Legislação Portugueza, anno de 1828, Lisbôa.

2 - Se algum devedor empenhar a seu credor alguma cousa móvel, ou de raiz, com condição que, não the pagando a dívida a dia certo, o penhor fique por ella vendido
} 
De que serviria ao esbulhador a defesa, alegando um domínio transferido ao esbulhador?

Considero a exceptio dominii inadmissível no direito consolidado por Teixeira de Freitas, embora julgue oportuna e correta a sua admissão no Código Civil Brasileiro, com a ressalva de não retardar o processo nas ações possessórias, caso não se prove logo o domínio.

Na posse para o usocapião, o código exige, nos artigos 550 e 551, exige que o usucapiente possua a coisa como sua, pois, em ambos os artigos insiste na expressão "possuir como seu", quando afirma: art. 550 - "Aquêle que, por vinte anos, sem interrupção, "nem oposição, possuir como seu um imóvel, adquirir-lhe-á" "o domínio, independentemente de título de boa fé, que," "em tal caso, se presume; podendo requerer ao juiz que" "assim o declare por sentença a qual servirá de título para" "a transcrição no registro de imóveis".

Artigo 551 -

"Adquire também o domínio do imóvel aquêle que, por" "dez anos entre presentes, ou quinze entre ausentes, o" "possuir como seu, contínua e incontestadamente, com" "justo título e boa-fé".

Está assim, inscrito nêsse trecho de nosso Código, expressamente a exigência do animus domini, à semelhança do direito romano que o exigia na posse ad usocapionem.

Ao contrário disto, nas ações possessórias, o Código não exige que o autor tenha possuido a coisa como sua, bastando, na forma do art. 486 the assista a posse denominada direta.

Parece-nos mais consentânea com a orientação de nosso código que se assegurasse a qualquer detentor de não ser molestado na detenção, arbitràriamente, por terceiro.

Não, teríamos, assim, o direito romano que Savigny expôs, com admirável e profunda ciência e que lhering deforma de maneira tão impressionante: mas sim um direito prático, lógico e atualizado.

\footnotetext{
e arrematado ao credor, mandamos que tal convença seia nenhuma e de nenhum effeito. Porém, se o devedor der alguma cousa sua em penhor a seu credor sob condição, que não lhe pagando a tempo certo, fique o penhor arrematado pelo justo preço, o tal apenhamento assi feito valerá, e a convença será guardada. E em este caso o penhor será estimado depois do tempo da paga per dous homens bons juramentados e escolhidos pelas partes, convém a saber, per cada hum seu, e ficará arrematado a credor por o preço, em que fôr estimado.
} 